\title{
"Metabolism of Odontoblast-like cells submitted to transdentinal irradiation with blue and red LED"
}

\author{
Leopoldina de Fátima Dantas de Almeida ${ }^{\mathrm{a}, *}$, Fernanda Gonçalves Basso ${ }^{\mathrm{b}}$, \\ Ana Paula Silveira Turrionic ${ }^{\mathrm{c}}$, Carlos Alberto de-Souza-Costa ${ }^{\mathrm{d}}$, Josimeri Hebling ${ }^{\mathrm{b}}$ \\ a School of Dentistry, Federal University of Paraíba, Cidade Universitária, $s / n$ - Castelo Branco, João Pessoa, PB, Brazil \\ b Department of Orthodontics and Pediatric Dentistry, Araraquara School of Dentistry, São Paulo State University, Rua Humaitá, 1680, Araraquara, SP, Brazil \\ c Department of Pediatric Dentistry, School of Dentistry, Federal University of Uberlândia, João Naves de Ávila Avenue, 2121, Uberlândia, MG, Brazil \\ d Department of Physiology and Pathology, Araraquara School of Dentistry, São Paulo State University, Rua Humaitá, 1680, Araraquara, SP, Brazil
}

\section{A R T I C L E I N F O}

\section{Key-words:}

phototerapy

light emitting diodes

odontoblasts

dentin

dental pulp

\begin{abstract}
A B S T R A C T
Objectives: The present study evaluated the trans-dentinal effect of light emitting diodes (LEDs) irradiation on the metabolism of odontoblast-like cells.

Methods: Seventy-two dentin discs $(0.2 \mathrm{~mm}$ thick) were obtained from human molar teeth. MDPC-23 cells (20,000 cells/disc) were seeded on the pulpal side of the discs using DMEM, supplemented with $10 \%$ fetal bovine serum (FBS). After $12 \mathrm{~h}$, the culture medium was replaced with DMEM containing 0.5\% FBS. After additional $12 \mathrm{~h}$, blue $(455 \pm 10 \mathrm{~nm})$ or red $(630 \pm 10 \mathrm{~nm})$ LEDs were used at irradiances of 80 and $40 \mathrm{~mW} / \mathrm{cm}^{2}$, respectively, to irradiate the occlusal side of the discs. The energy doses were fixed at $2 \mathrm{or} 4 \mathrm{~J} / \mathrm{cm}^{2}$. Cell viability, alkaline phosphatase activity (ALP), total protein production and collagen synthesis were evaluated $72 \mathrm{~h}$ after irradiation. Data were submitted to Kruskal-Wallis and Mann-Whitney tests $(\alpha=0.05)$.

Results: Red light promoted proliferative effects at the energy dose of $4 \mathrm{~J} / \mathrm{cm}^{2}$. Conversely, cell cultures irradiated with $2 \mathrm{~J} / \mathrm{cm}^{2}$ emitted by the blue light showed reduced viability. ALP production was stimulated by red light in comparison with blue light at $4 \mathrm{~J} / \mathrm{cm}^{2}$. Total protein production was reduced after exposure to blue light at $4 \mathrm{~J} / \mathrm{cm}^{2}$, while no effect was observed on collagen production.

Conclusions: Irradiation with red LED at $4 \mathrm{~J} / \mathrm{cm}^{2}$ bio-stimulated the viability of odontoblast-like cells, whilst blue light had unfavorable effects on the cellular metabolism.
\end{abstract}

\section{Introduction}

The biological integrity of the dental pulp complex is frequently challenged by the progression of dental caries lesions (Cooper, Holder, \& Smith, 2014), absence of dentinal tubule sealing (Oliveira et al., 2011), operatory procedures and the use of restorative materials (Goldberg \& Smith, 2004; Nicholson \& Czarnecka, 2008). However, the damage to the pulp tissue may be mitigated, particularly by means of modulating inflammation and tissue repair that culminates in the deposition of dentinal matrix (Carroll, Milward, Cooper, Hadis, \& Palin, 2014), either by primary odontoblasts or newly differentiated mesenchymal cells (Tjäderhane \& Haapasalo, 2009). Thus, therapies that allow bio-stimulation have been designed to aid pulp repair (Carroll et al., 2014).

It has been demonstrated that low level phototherapy is able to positively modulate the inflammatory reaction and the production of extracellular matrix in tissues (i.e.: skin), and in cell cultures of fibroblasts, osteoblasts and keratinocytes (Carroll et al., 2014; Frigo et al., 2010; Pyo et al., 2013). However, the effect of light therapies on pulp cells response has been scarcely evaluated (de Almeida, Basso, Turrioni, De-Souza-Costa, \& Hebling, 2016; Holder, Milward, Palin, Hadis, \& Cooper, 2012; Turrioni et al., 2014). Devices such as LASER (Light Amplification by Stimulated Emission of Radiation) and LED (Light Emitting Diodes), are used at low irradiance and energy dose values to stimulate tissues and cells (Huang, Chen, Carroll, \& Hamblin, 2009; Posten et al., 2005). The wavelengths most used are in the range of 600 - 800 nm (AlGhamdi, Kumar, \& Moussa, 2012; Carroll et al., 2014; Posten et al., 2005). Although the blue wavelength is not included within this optical window (Huang et al., 2009), it is extensively used in Dentistry for light-activating restorative materials and cavity liners (Krämer, Lohbauer, García-Godoy, \& Frankenberger, 2008). Therefore, the investigation of the effect of blue light in the metabolism of pulp cells is worthwhile.

When light-activating dental materials applied on dentin, pulp cells

\footnotetext{
* Corresponding author.

E-mail address: leopoldinalmeida@hotmail.com (L.d.F.D.d. Almeida).
} 
might be affected since the dentin allows the transmittance of the light through its inherently tubular structure. Although some studies have evaluated the effects of phototherapy with blue light (Kushibiki, Tajiri, Ninomiya, \& Awazu, 2010; Lewis et al., 2005; Liebmann et al., 2010; Wataha, Lockwood, Lewis, Rueggeberg, \& Messer, 2004), there is still no consensus about the real effects promoted by exposure to this wavelength, particularly on the pulp tissue or cell cultures such as odontoblasts and fibroblasts cells, which may be exposed to the effect of the blue LED light during the photo-activation of dental materials.

In spite of some studies have demonstrated that infrared laser may improve type I collagen gene expression (Pyo et al., 2013) and result in positive effects on human pulp culture (Turrioni et al., 2014) clinical conditions for the application of infrared therapy has been not simulated. Most in vitro studies evaluated the effects of these light sources directly on cell cultures, only considering the light therapy as a possible (and distant) application for modulation of pulp inflammation, or for the stimulation of pulp mesenchymal cells. However, these possible beneficial effects have not been evaluated in models in which the presence of dentin should be considered, determining the effects of light scattering. In order to evaluate the efficacy of phototherapy in a simulated model of pulp inflammation, the presence of mineralized tissue as well as its thickness should be considered during the irradiance procedure

Therefore, the present study evaluated the effects of blue (455 nm) and red $(630 \mathrm{~nm})$ LEDs in a trans-dentinal model on odontoblast-like cells, simulating the application of phototherapy in deep cavities.

\subsection{Material and Methods}

\subsubsection{Dentin discs and measurement of LED light attenuation}

A total of 78 human third molars were used after the approval from the Research Ethics Committee (CAAE 13072813.2.0000.5416) of the Araraquara School of Dentistry - UNESP. The teeth were cut and ground (Turrioni et al., 2016) to obtain dentin discs with a final thickness of $0.2 \mathrm{~mm}$. The smear layer was removed by applying an EDTA $0.5 \mathrm{M}$ (pH 7.2) solution for 30 seconds on both surfaces of the discs, and subsequent deionized water rinsing for 60 seconds.

The dentin discs were then submitted to the evaluation of light attenuation for each wavelength. Using a high sensitivity sensor for wavelengths between 400 and $1060 \mathrm{~nm}$ coupled to a potentiometer (LM-2, Coherent, California, USA), the light attenuation generated by each disc was determined. Initially, the pulp surface of each specimen was placed in contact with the sensor, and the LED, according to each wavelength, irradiated the occlusal surface for 5 seconds (Turrioni et al., 2013). The irradiance values were recorded before the disc was inserted and afterwards, and the light attenuation was calculated for the disc, then cell monolayers received 40 and $80 \mathrm{mw} / \mathrm{cm}^{2}$, depending on the wavelength. Using that data, the discs were homogeneously distributed into 6 groups ( 3 for each wavelength) in such a way that the means of light attenuation of all groups were statistically not different (ANOVA, $\mathrm{p}>0.05)$.

\subsection{Irradiation Device and Physical Parameters}

The cell culture was irradiated with two devices denominated LEDTables (developed by the Optics Group of the Federal University of São Carlos, São Carlos SP, Brazil), which had 24 light emitting diodes at the blue $(455 \pm 10 \mathrm{~nm}-$ peak \pm standard deviation $)$ or red $(630 \pm 10 \mathrm{~nm}-$ peak \pm standard deviation) wavelengths. The irradiation parameters used were: irradiance of $80 \mathrm{~mW} / \mathrm{cm}^{2}$ for the blue wavelength, and $40 \mathrm{~mW} / \mathrm{cm}^{2}$ for the red wavelength, due to scattering of wavelengths and evaluation of loss of power of the dentin discs. The energy doses used were fixed at $2 \mathrm{~J} / \mathrm{cm}^{2}$ and $4 \mathrm{~J} / \mathrm{cm}^{2}$, and the irradiation times were calculated considering the distinct irradiance and distance between the irradiated area and the diodes $(11 \mathrm{~mm})$ (Chart 1). The physical parameters were measured periodically (every month).
Chart 1

Irradiation times for each LED wavelength and energy dose.

\begin{tabular}{lll}
\hline Wavelength (nm) & $\begin{array}{l}\text { Energy Dose } \\
2 \mathrm{~J} / \mathrm{cm}^{2}\end{array}$ & $4 \mathrm{~J} / \mathrm{cm}^{2}$ \\
\hline 450 & $25 \mathrm{~s}$ & $50 \mathrm{~s}$ \\
630 & $50 \mathrm{~s}$ & $100 \mathrm{~s}$ \\
\hline
\end{tabular}

Immediately before light irradiation, the culture medium DMEM was replaced by plain PBS solution at same temperature $\left(37^{\circ} \mathrm{C}\right)$. PBS was kept in contact the cells during the whole irradiation time. Afterwards, the PBS was removed and the cells were kept in contact with fresh culture medium. In addition, the temperature $\left(37^{\circ} \mathrm{C}\right)$ was monitored by means of a multimeter and thermistor coupled to the base of the diodes, previously calibrated. The irradiation was performed in a dark room and each cell culture was irradiated only once with the designated wavelength.

\subsection{Cell Culture}

MDPC-23 cells (odontoblast-like cells) were thawed and sub-cultivated in DMEM supplemented with $10 \%$ fetal bovine serum (FBS) (Gibco, Grand Island, NY, USA), $100 \mathrm{IU} / \mathrm{mL}$ of penicillin, $100 \mathrm{~g} / \mathrm{mL}$ of streptomycin and $2 \mathrm{mmol} / \mathrm{L}$ of glutamin (Gibco, Grand Island, NY, USA). The cells were maintained in an atmosphere with $5 \% \mathrm{CO}_{2}$ at $37{ }^{\circ} \mathrm{C}$ until the number of cells required for the experiments were obtained.

\subsection{Experimental Conditions}

After allocating the discs ( $n=12$ per group) to groups that were homogeneous with regard to light attenuation, the diameter of the discs was reduced to a final diameter of $8 \mathrm{~mm}$. Then, the dentin discs were individually stored in plastic sleeves and sterilized with ethylene oxide. Each dentin disc was mounted in an artificial pulp metal device using silicone O-rings, all previously sterilized. Each set was inserted upside down into a well of a 24-well acrylic plate in such a way that the occlusal surface of the disc was in contact with acrylic at the bottom of the culture plate. MDPC-23 cells were seeded at a density of 20,000/disc, in DMEM containing $10 \%$ FBS, on the pulpal side of the discs. After $12 \mathrm{~h}$, the culture medium was replaced by fresh DMEM supplemented with $0.5 \%$ FBS, with the purpose of inducing nutritional deficit in the cells (data not published). After additional $12 \mathrm{~h}$, the samples were exposed to a single LED irradiation according to the proposed parameters. The morphological and metabolic evaluations were performed after $72 \mathrm{~h}$ from irradiation. Non-irradiated control groups were treated exactly like the irradiated groups, including placing the culture plate on the LEDTable, except that the diodes were not activated. In the control groups (non-irradiated cells), cells were kept in the LEDTable for the longest time of each wavelength, which was $50 \mathrm{~s}$ for the blue light and $100 \mathrm{~s}$ for the red light.

\subsection{Cell Viability}

After $72 \mathrm{~h}$ from irradiation, cell viability was evaluated by the Alamar blue assay $(n=8)$ at the concentration of $10 \%$ [21]. After 3 hours of incubation of the Alamar Blue solution, $200 \mu \mathrm{L}$ of the extract was transferred to 96-well plates and the fluorescence was determined (excitation/emission - $485 \mathrm{~nm} / 530 \mathrm{~nm}$ ). The values obtained were normalized by the median of the control group ( $=100 \%$ cell viability) and transformed into percentages.

\subsection{Total Protein Production and Alkaline Phosphatase activity}

Initially, the cells were lysed by the addition of a detergent agent, 
Table 1

Viability of MDPC-23 cells after blue-LED and red-LED irradiation using different energy doses.

\begin{tabular}{lccc}
\hline \multirow{2}{*}{ LED } & \multicolumn{3}{c}{ Energy Doses } \\
\cline { 2 - 4 } & 0 & $2 \mathrm{~J} / \mathrm{cm}^{2}$ & $4 \mathrm{~J} / \mathrm{cm}^{2}$ \\
\hline Blue & $100.0(88.4-139.2) \mathrm{a}$ & $68.3(54.6-77.1) \mathrm{b}$ & $115.5(59.3-120.2) \mathrm{a}\urcorner^{*}$ \\
& & & \\
Red & $100.0(95.7-125.4) \mathrm{B}$ & $173,6(147.2-220.1) \mathrm{A}^{-}$ & $219.3(189.3-355.7) \mathrm{A}^{\lrcorner}$ \\
\hline
\end{tabular}

Values indicate median (percentile 25-percentile 75), $\mathrm{n}=8{ }^{\text {aA }}$ For each LED type (rows): medians identified by the same letter are not statistically different. Medians connected by the asterisk within each column are statistically different (Mann-Whitney, $\mathrm{p}<0.05$ ).

and then $50 \mu \mathrm{L}$ of the extract was used for alkaline phosphatase quantification. The remaining $950 \mu \mathrm{L}$ were used for analyzing the total protein content $(n=8)$ by the method proposed by Read \& Northcote (1981). The colorimetric reaction was read at $655 \mathrm{mn}$ to determine absorbance. These values were interpolated in a linear equation (standard curve) that was constructed, based on known bovine albumin concentrations $(\mathrm{mg} / \mathrm{mL})$. The total protein concentration was normalized by the median of the control group $(=100 \%)$ of each wavelength and transformed into percentage.

Alkaline phosphatase activity $(n=8)$ was measured using the end point assay kit (Labtest Diagnostico SA, Lagoa Santa, MG, Brazil) (Read \& Northcote, 1981). The colorimetric assay determines the enzymatic activity by means of hydrolysis of thymol-phthalein monophosphate, releasing thymolphthalein. Absorbance was determined at $590 \mathrm{~nm}$, with the values found being interpolated in a standard curve (U/L). After this, the values were normalized by the median of the control group ( $=100 \%$ ) and transformed into percentages.

\subsection{Collagen Synthesis}

Collagen production $(n=8)$ was determined by means of Sirius Red assay (Saruwatari et al., 2005). The extracts were collected in Eppendorf flasks at $-20{ }^{\circ} \mathrm{C}$. Three hundred microliters were transferred to tubes containing $300 \mu \mathrm{L}$ of Sirius Red dye (Direct Reagent) and kept under agitation at $400 \mathrm{rpm}, 25^{\circ} \mathrm{C}$ for 1 hour. After this, the samples were centrifuged at $12,000 \mathrm{rpm}$ for 10 minutes. The pellets formed were washed with $500 \mu \mathrm{L}$ of $0.1 \mathrm{M} \mathrm{HCl}$ solution, and then $250 \mu \mathrm{L}$ of $0.5 \mathrm{M} \mathrm{NaOH}$ was added to promote dissolution. The samples were vortexed at $200 \mu \mathrm{L}$ and then transferred to 96-well plates for readout of absorbance at $555 \mathrm{~nm}$. The values were normalized by the median of the control group $(=100 \%)$ and transformed into percentages.

\subsection{Cell Morphology}

Cell morphology was evaluated by scanning electron microscopy $(n=2)$. The dentin discs were carefully removed from the artificial pulp devices and fixed with glutaraldehyde $2.5 \%$ for 120 minutes. Subsequent fixation and drying steps were performed in accordance with the method proposed by Oliveira et al. (2011). The discs were mounted on metal stubs and kept in a desiccator for 1 week. The samples were gold-sputtered and evaluated by scanning electron microscopy (SEM; FEG-MEV; JEOL model 7500, Japan) at 200X and 500X magnifications. Under SEM, cell morphology was assessed from at least 8 random fields, selected according to the presence of cells. From those, two representative images (under 2 different magnifications) were selected for each group to illustrate the cell morphology effect. The MDPC-23 cell morphology was observed for each group and analyzed descriptively, particularly with regards to the dentin area covered by the cells and cytoplasm conformation.

\subsection{Data Analysis}

Data of cell viability, total protein production, alkaline phosphatase and collagen synthesis did not present normal distribution. Therefore, they were submitted to the nonparametric Kruskal-Wallis test complemented by Mann-Whitney U-tests with Bonferroni correction. The level of significance of $5 \%$ was established for all the statistical inferences.

\section{Results}

\subsection{Cell Viability}

Cell viability (Table 1 ) was negatively affected when the culture was irradiated with $2 \mathrm{~J} / \mathrm{cm}^{2}$ using the blue wavelength, compared to control group and the samples irradiated with $4 \mathrm{~J} / \mathrm{cm}^{2}$. For the red LED, both energy doses were able to significantly increase the cellular metabolism in comparison to the control (non-irradiated cells). When the energy doses were compared to each other within each energy dose, cultures irradiated with the red light had significantly higher metabolism than cultures irradiated with the blue LED (Table 1).

\subsection{Total Protein Production and Alkaline Phosphatase Activity}

Total protein production was negatively affected by exposure to blue LED only at $4 \mathrm{~J} / \mathrm{cm}^{2}$, statistically differing from the control group. However, no difference was detected between $4 \mathrm{~J} / \mathrm{cm}^{2}$ and $2 \mathrm{~J} / \mathrm{cm}^{2}$ (Table 2). Total protein production was not affected by red light irradiation. No difference between the energy doses of $2 \mathrm{~J} / \mathrm{cm}^{2}$ and $4 \mathrm{~J} / \mathrm{cm}^{2}$ were revealed, and the values did not differ from those of the control group (Table 2). When comparing the wavelengths within the same energy dose, the red LED stimulated a statistically higher production of total protein when $4 \mathrm{~J} / \mathrm{cm}^{2}$ were delivered to the cells while no difference was seen when the cells were irradiated with only $2 \mathrm{~J} / \mathrm{cm}^{2}$ (Table 2).

The activity of alkaline phosphatase was reduced by exposure to LED to the blue wavelength, in comparison with the control group, irrespective of the energy dose delivered to the cells (Table 3). The same was observed when the cells were irradiated with red light at $2 \mathrm{~J} / \mathrm{cm}^{2}$, while at $4 \mathrm{~J} / \mathrm{cm}^{2}$ had no effect on the synthesis of this protein. Comparing the wavelengths within each energy dose, the red LED was superior to the blue LED only at $4 \mathrm{~J} / \mathrm{cm}^{2}$ (Table 3).

\subsection{Collagen Synthesis}

Collagen synthesis was not affected by exposure to blue or red LEDs, irrespective of the energy dose delivered to the MDPC-23 cells (Table 4).

Table 2

Total protein production by MDPC-23 cells after blue-LED and red-LED irradiation using different energy doses.

\begin{tabular}{lccc}
\hline \multirow{2}{*}{ LED } & \multicolumn{3}{c}{ Energy Dose } \\
\cline { 2 - 4 } & 0 & $2 \mathrm{~J} / \mathrm{cm}^{2}$ & $4 \mathrm{~J} / \mathrm{cm}^{2}$ \\
\hline Blue & $101.1(93.8-108.5) \mathrm{a}$ & $84.8(61.8-98.5) \mathrm{ab}$ & $57.1(46.0-76.7) \mathrm{b} \neg$ \\
& & & $*$ \\
Red & $102.9(85.6-115.5) \mathrm{A}$ & $75.9(58,3-93.1) \mathrm{A}$ & $89.8(75.3-103.8) \mathrm{A}^{-}$
\end{tabular}

Values indicate median (percentile 25-percentile 75), $\mathrm{n}=8 .{ }^{\mathrm{aA}}$ For each LED type (rows): medians identified by the same letter are not statistically different. Medians connected by the asterisk within each column are statistically different (Mann-Whitney, $\mathrm{p}<0.05$ ). 
Table 3

Alkaline phosphatase activity by MDPC-23 cells after blue-LED and red-LED irradiation using different energy doses.

\begin{tabular}{lccc}
\hline \multirow{2}{*}{ LED } & \multicolumn{3}{c}{ Energy Dose } \\
\cline { 2 - 4 } & 0 & $2 \mathrm{~J} / \mathrm{cm}^{2}$ & $4 \mathrm{~J} / \mathrm{cm}^{2}$ \\
\hline Blue & $100.0(81.3-117.0) \mathrm{a}$ & $42.1(31.0-55.8) \mathrm{b}$ & $21.9(13.5-41.8) \mathrm{b}\urcorner_{*}^{*}$ \\
Red & $99.9(47.5-108.7) \mathrm{A}$ & $47.6(22.9-53.9) \mathrm{B}$ & $118.3(58.4-329.4) \mathrm{A}^{\lrcorner}$
\end{tabular}

Values indicate median (percentile 25-percentile 75), $\mathrm{n}=8{ }^{\mathrm{aA}}$ For each LED type (rows): medians identified by the same letter are not statistically different. Medians connected by the asterisk within each column are statistically different (Mann-Whitney, $\mathrm{p}<0.05$ ).

Table 4

Collagen production by MDPC-23 cells after blue-LED and red-LED irradiation using different energy doses.

\begin{tabular}{lccc}
\hline \multirow{2}{*}{ LED } & \multicolumn{3}{c}{ Energy Dose } \\
\cline { 2 - 4 } & 0 & $2 \mathrm{~J} / \mathrm{cm}^{2}$ & $4 \mathrm{~J} / \mathrm{cm}^{2}$ \\
\hline Blue & $100.0(85.8-106.2)$ & $77.6(76.1-85.3)$ & $83.3(76.6-85.7)$ \\
Red & $99.8(85.5-111.3)$ & $82.9(67.7-95.2)$ & $108.5(62.5-124.0)$
\end{tabular}

Values indicate median (percentile 25-percentile 75), $\mathrm{n}=8$. No statistically significant differences were detected among groups (Kruskal-Wallis, $\mathrm{p}>0.05$ ).

\subsection{Cell Morphology}

The cell morphology evaluated by SEM, using representative fields (Figs. 1-3) revealed that the MDPC-23 cells presented morphological characteristics compatible with normality when irradiated with the two wavelengths (blue and red LED), irrespective of the energy dose $(2 \mathrm{~J} /$ $\mathrm{cm}^{2}$ or $4 \mathrm{~J} / \mathrm{cm}^{2}$ ). The normal morphology of MDPC-23 cells is characterized by a large and flat cellular cytoplasm with multiple small cytoplasmic projections (Fig. 1) that are responsible for cell adherence to the substrate (Figs. 2 and 3). The main difference observed was the lower number of cells attached to the dentin when the culture was irradiated with blue LED at the energy dose of $2 \mathrm{~J} / \mathrm{cm}^{2}$. As a consequence of the cellular detachment, a larger area of exposed dentin with evident open dentin tubules is seen (Figs. 2c and d).

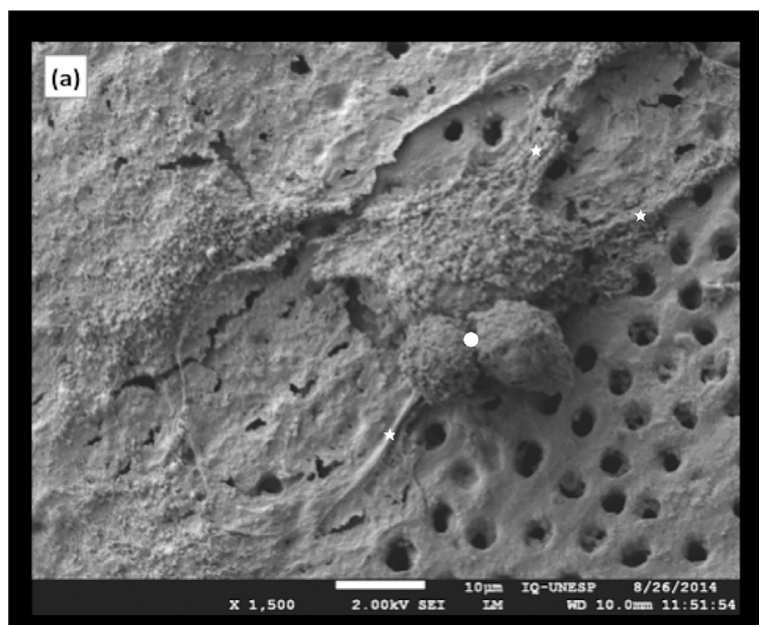

Fig. 1. SEM photomicrography of MDPC-23 cells irradiated with $4 \mathrm{~J} / \mathrm{cm}^{2}$ dose by redLED. Cells present normal morphology, also showing wide cytoplasm and cellular projections (stars). Besides that, it was observed the mitosis (ball). Magnification: 1,500 $\times$.

\section{Discussion}

Odontoblasts are cells present in the pulp tissue, specialized in dentin matrix secretion and responsible for sensory transmission (Couve, Osorio, \& Schmachtenberg, 2013). They are the first defense barrier against harmful stimuli to the tooth (Arana-Chavez \& Massa, 2004). For this reason, immortalized MDPC-23 cells were used in the present study, since they present the phenotype of odontoblasts (Man, Shelton, Cooper, \& Scheven, 2012). Additionally, MDPC-23 cells are notably mineralized matrix producers, from the secretion of dentinphosphoprotein and sialoprotein from the dentin matrix (Couve, Osorio, \& Schmachtenberg, 2013), thus mimicking the clinical condition of a very deep cavity, with small dentin layer.

The cell cultivation protocol, in which cellular nutritional deficit was induced by lowering the concentration of fetal bovine serum, was performed based on previously conducted studies (Basso et al., 2016). This method allows the MDCP-23 odontoblast-like cells to maintain viability even in the presence of low serum coenzymes, and the effects of photo-stimulation are detectable, considering the fact that the cellular microenvironment must have some type of deficit for proliferative effects to occur. Besides that, the response to photo-bio-stimulation is better observed when the cells are submitted to nutritional deficit or other debilitating effect, such as a reduction in oxygen levels (Aleksic et al., 2010; Peplow et al., 2011).

Moreover, a trans-dentinal model was used to evaluate the effects of the phototherapy, with the interposition of $0.2 \mathrm{~mm}$-thick dentin discs. This purpose of this design was to simulate very deep cavities without pulp exposure; a clinical condition in which it would be necessary to use an indirect capping material. The dentin discs standardization at $0.2 \mathrm{~mm}$ thickness determined that there was light passing, even with loss of irradiance, which was properly adjusted. In addition, the collected samples were extracted from young teeth, in an attempt to standardize the dentin substrate on the number of tubules and presence of inter-tubular dentin. Higher thicknesses such as 0.5 or $1.0 \mathrm{~mm}$ would attenuate the blue light more effectively, so a higher value of irradiance would be necessary to allow the light passage (Turrioni et al., 2013). Compared to red LED, blue light attenuation through dentin discs is higher.

Under these conditions, low intensity phototherapy would act helping to modulate inflammation and pulp tissue repair through the dentin tissue. The presence of dentin may influence the direction and scattering of light (Kienle, Michels, \& Hibst, 2006; Turrioni et al., 2013) due to its anisotropic behavior (Kienle, Michels, \& Hibst, 2006). Because of this phenomenon, therefore, the irradiances in the present study were adjusted considering the dentin barrier, and also according to the wavelength. It is know that longer wavelengths, such as the red or infrared type, have greater light penetration (Huang et al., 2009) whereas the blue light has less penetration into tissues and greater scattering (Neupane, Ghimire, Shakya, Chaudhary, \& Shrivastava, 2010).

Although the dentin specimens were of the same thickness and the irradiances were adjusted in order to homogenize the energy doses, notable differences were found among the samples exposed to the different wavelengths, mainly in the evaluation of cell viability. Red LED increased cell proliferation at both doses, what was not observed for blue LED. Red light probably exceeded the threshold of cell excitation, and thus the response mechanisms began to operate, allowing increase in proliferation (Emelyanov \& Kiryanova, 2015).

Moreover, red light is known to present less scattering and losses during its trajectory when compared with the blue light (Neupane et al., 2010). It can be suggested that during cell exposure to the blue LED, the light dissipation impaired reaching target cells effectively (Turrioni et al., 2016). Another parameter considered was the temperature change by light exposition. In pilot studies it was determined that the temperature variation for exposure to blue light was $2{ }^{\circ} \mathrm{C}$, whilst for red light there was no expressive variation during 10 minutes of exposure 


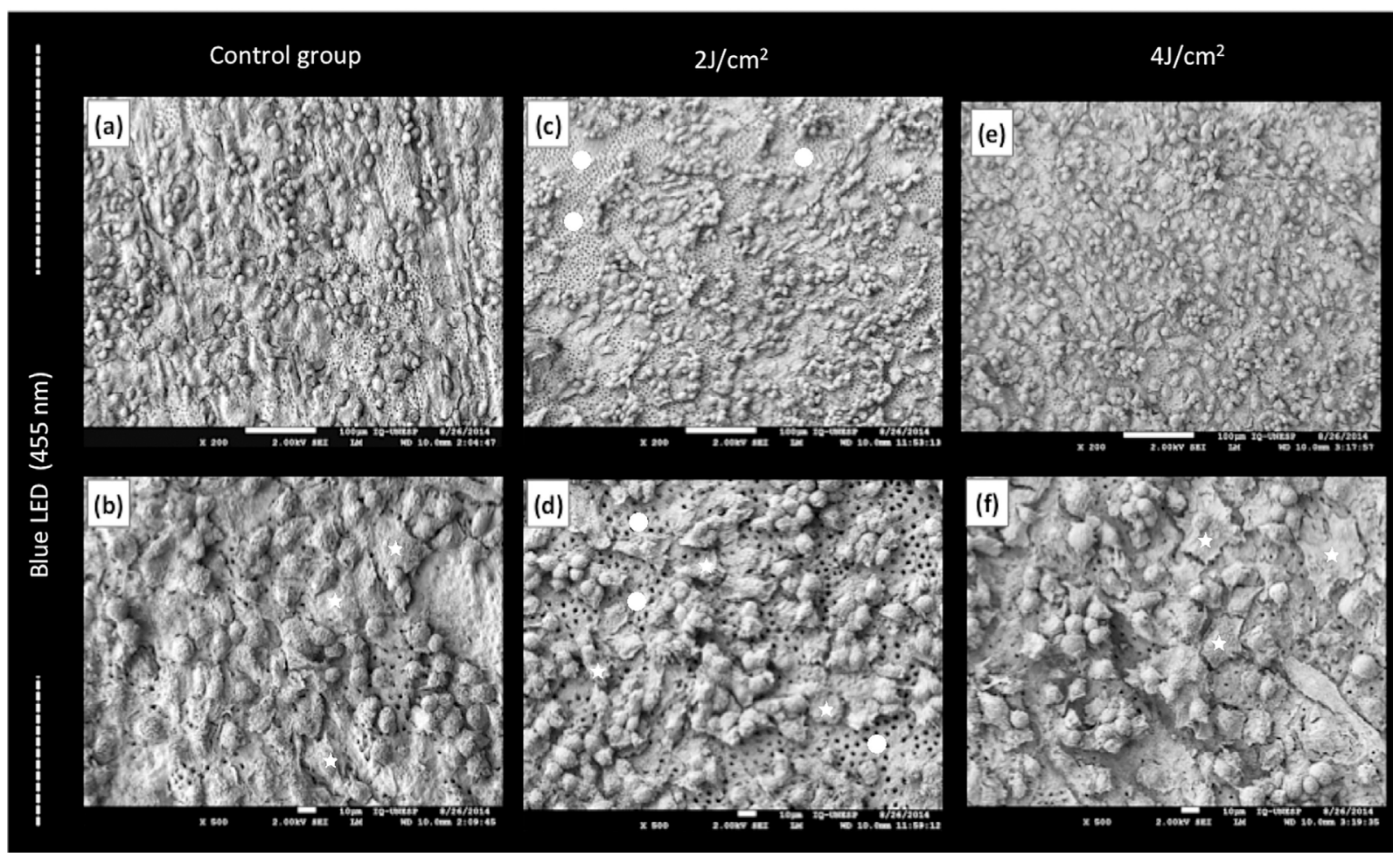

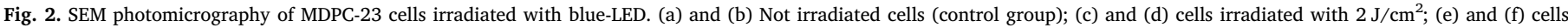

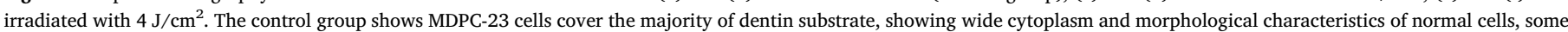

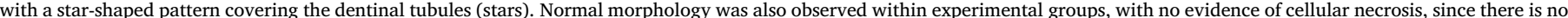

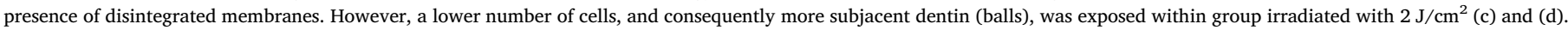
Magnifications: $200 \times$ and $500 \times$

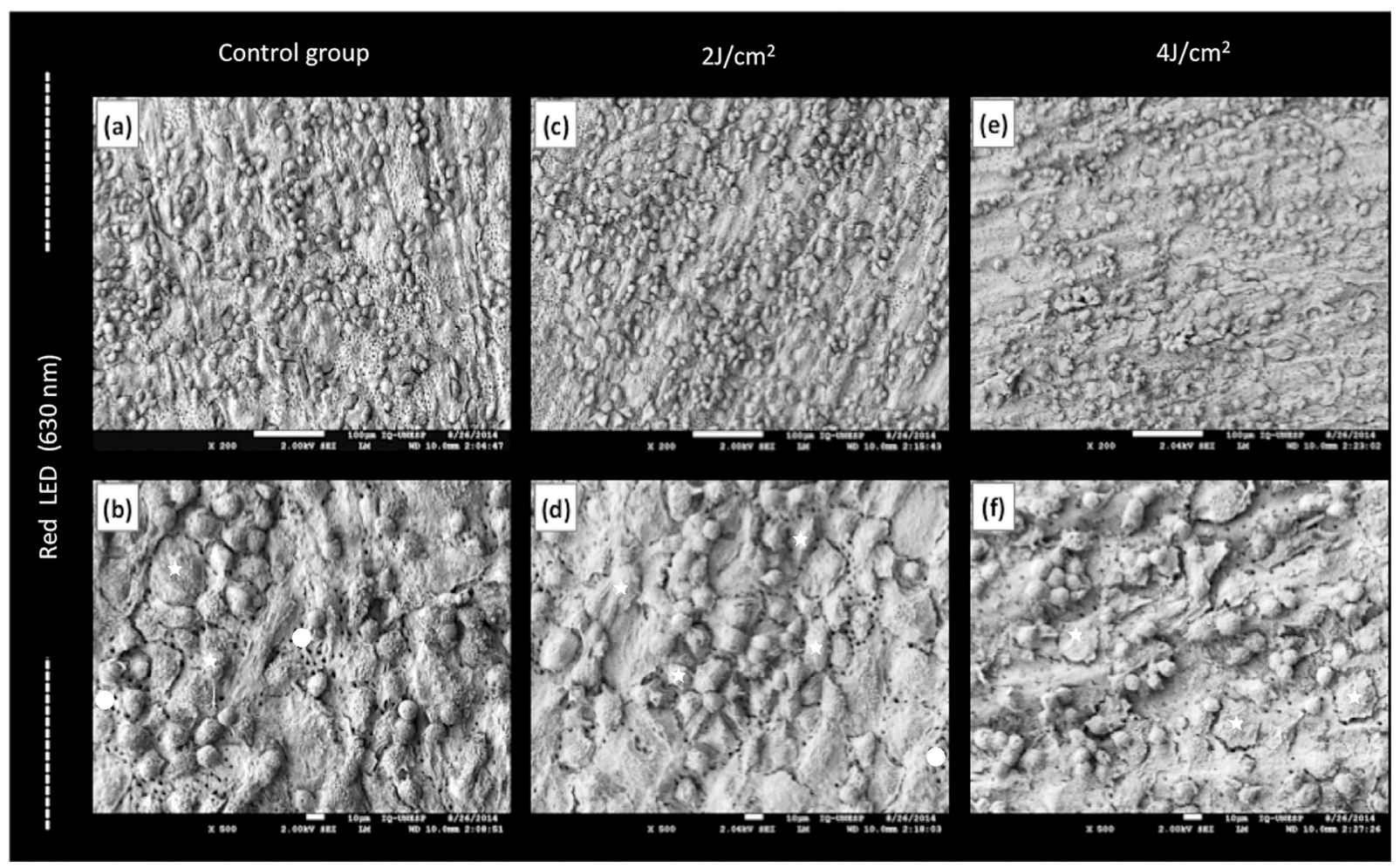

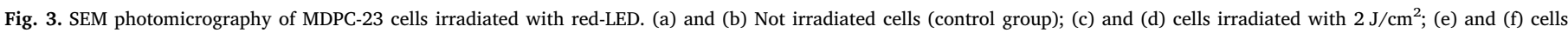

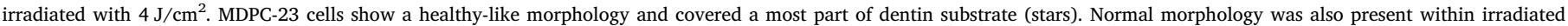

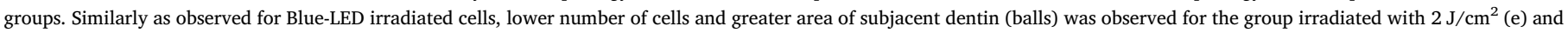
(f). Magnifications: $200 \times$ and $500 \times$. 
to the diodes (data not shown). It is recognized that the time evaluated for temperature assessments was greater than the longer exposure time of the cells to the light. In addition, only a temperature higher than $3.4{ }^{\circ} \mathrm{C}$ is capable of promoting damage to the culture of the MDPC-23 cell line (Souza et al., 2009), then it is suggested that change of temperature was not able to promote effects in the cell culture.

The primary effect of phototherapy has been attributed to the increase in ATP production, by means of activating chromophores present in the cellular respiratory chain, with consequent increase in DNA synthesis (Prindeze, Moffatt, \& Shupp, 2012) and cell proliferation (Carroll et al., 2014; Huang et al., 2009). However, these target cells require specific wavelengths for their stimulation. Enzymes such as cytrochrome c oxidase and flavoproteins, present in the cellular respiratory chain, may be stimulated by light sources at the red and blue wavelengths, respectively (Buravlev, Zhidkova, Osipov, \& Vladimirov, 2015; Carroll et al., 2014; Huang et al., 2009; Kushibiki et al., 2010).

It has been described that the blue wavelength is absorbed by porphyrins, existent in larger concentrations in hemoglobin and myoglobin (Medlock et al., 2015), with the metabolic degradation products of these molecules being considered toxic (Imada, Tanaka, Ibaraki, Yoshimura, \& Ito, 2014). It could be suggested that this mechanism could have been responsible for the cytotoxic effects on the MDPC-23 cells irradiated with the blue light at a dose of $2 \mathrm{~J} / \mathrm{cm}^{2}$, while no effect on cellular metabolism was seen when $4 \mathrm{~J} / \mathrm{cm}^{2}$ was were delivered to the cells (Almeida et al., 2016). Conversely, the red light significantly increased cell proliferation rates, as previously demonstrated (Almeida et al., 2017; Holder et al., 2012; Turrioni et al., 2014), although the present study did not assess which chromophores targeted the phototherapy.

It is known that low intensity phototherapy has biphasic effects on biological systems, which are dependents of irradiance, energy dose and wavelength used (Huang, Chen, Carroll, \& Hamblin, 2009). Thus, this effect can not be considered linear (Emelyanov \& Kiryanova, 2015). Besides that, each specific wavelength can inhibit or stimulate specific cellular chromophores according to their band of absorption, however only suggestions of possible cellular targets are mentioned in the literature (Huang, Chen, Carroll, \& Hamblin, 2009).

The total protein production and alkaline phosphatase activity were significantly reduced by irradiation with the blue LED. The red light promoted no deleterious effects, except for the dose of $2 \mathrm{~J} / \mathrm{cm}^{2}$, which reduced ALP production in comparison with the concurrent non-irradiated control. Phototherapy has been reported to exert a biphasic effect on cell responses (Huang, Chen, Carroll, \& Hamblin, 2009); that is, the response to phototherapy may not be linear, therefore, higher doses may not necessarily cause more damage to cells or tissues.

Irradiation with the red light $(600-700 \mathrm{~nm})$ emitted by both LASER and LED has shown promising results in general. However, when evaluating the effects of the red light on the differentiation of some types of cells, the results were not always positive (Holder et al., 2012; Kim et al., 2009; Zaccara et al., 2015). In the present study, it was seen that the higher dose did not improve the ALP activity, a fundamental enzyme in the process of dentin matrix deposition and mineralization (Tjäderhane \& Haapasalo, 2009). Therefore, the phototherapy acts by giving support to these processes (Huang et al., 2009) and further investigations are necessary to evaluate the efficacy of the phototherapy in the presence of growth factors, for instance.

In addition to ALP synthesis, odontoblast-like cells secrete collagen type I, the main protein in the dentin matrix (Couve et al., 2013; Goldberg \& Smith, 2004). Therefore, the evaluation of collagen synthesis would indicate a possible application of phototherapy in aiding the pulp repair. However, the two wavelengths did not increase the production of this protein, irrespective of the energy doses delivered to the cells.

The physical parameters capable of photo-bio-stimulating immortalized pulp or mesenchymal cells have been investigated (Turrioni et al., 2014; Holder et al., 2012; Oliveira et al., 2011). However, the lack of uniformity among studies (i.e.: not standardized irradiance, energy dose, area of irradiated surface and even the cell cultivation regimen) is held responsible for the controversial results for phototherapy, in spite of being promising.

The trans-dentinal effects of blue, red and infrared wavelengths were investigated by Turrioni et al. (2015), using MDPC-23 cells and energy doses of $4 \mathrm{~J} / \mathrm{cm}^{2}$ and $25 \mathrm{~J} / \mathrm{cm}^{2}$ (irradiance of $88 \mathrm{~mW} / \mathrm{cm}^{\mathrm{z}}$ ). According to the authors, red and infrared LEDs showed superior results in comparison with blue LED, as seen in the present study when comparing the blue and the red LEDs. The overall good results for the red light generated by LEDs make its use relevant. Based on that, further studies should be performed to support the clinical recommendation of this phototherapy.

\section{Conclusion}

Irradiation of MDPC-23 odontoblast-like cells with blue LED did not stimulate cell proliferation and the production of proteins related to mineralized matrix deposition, whereas irradiation with red LED at the energy dose of $4 \mathrm{~J} / \mathrm{cm}^{2}$ increased cell viability.

\section{Acknowledgements}

The authors acknowledge with thanks the financial support provided by the Brazilian financing agenciesFAPESP (São Paulo State Research Supporting Foundation - grant 2012/17552-2). We declare no conflicts of interest.

\section{References}

Aleksic, V., Aoki, A., Iwasaki, K., Takasaki, A. A., Wang, C.-Y., Abiko, Y., \& Izumi, Y. (2010). Low-level Er:YAG laser irradiation enhances osteoblast proliferation through activation of MAPK/ERK. Lasers in Medical Science. http://dx.doi.org/10.1007/ s10103-010-0761-5.

AlGhamdi, K. M., Kumar, A., \& Moussa, N. A. (2012). Low-level laser therapy: a useful technique for enhancing the proliferation of various cultured cells. Lasers in Medical Science, 27(1), 237-249. http://dx. doi.org/10.1007/s10103-011-0885-2.

Almeida, L. de F. D., Turrioni, A. P. S., Basso, F. G., Montoro, L. A., de Souza-Costa, C. A., \& Hebling, J. (n.d.). Red LED Photobiomodulates the Metabolic Activity of Odontoblast-Like Cells. Brazilian Dental Journal, 27(4), 375-380. http://doi.org/10. 1590/0103-6440201600152.

Arana-Chavez, V. E., \& Massa, L. F. (2004). Odontoblasts: the cells forming and maintaining dentine. The International Journal of Biochemistry \& Cell Biology, 36(8), 1367-1373. http://dx.doi.org/10.1016/j.biocel.2004.01.006.

Basso, F. G., Turrioni, A. P. S., Almeida, L. F., Soares, D. G., Oliveira, C. F., Hebling, J., \& de Souza Costa, C. A. (2016). Nutritional deprivation and LPS exposure as feasible methods for induction of cellular - A methodology to validate for vitro photobiomodulation studies. Journal of Photochemistry and Photobiology. B Biology, 159, 205-210. http://dx.doi.org/10.1016/j.jphotobiol.2016.04.001.

Buravlev, E. A., Zhidkova, T. V., Osipov, A. N., \& Vladimirov, Y. A. (2015). Are the mitochondrial respiratory complexes blocked by NO the targets for the laser and LED therapy? Lasers in Medical Science, 30(1), 173-180. http://dx.doi.org/10.1007/ s10103-014-1639-8.

Carroll, J. D., Milward, M. R., Cooper, P. R., Hadis, M., \& Palin, W. M. (2014). Developments in low level light therapy (LLLT) for dentistry. Dental Materials: Official Publication of the Academy of Dental Materials, 30(5), 465-475. http://dx.doi.org/10. 1016/j.dental.2014.02.006.

Cooper, P. R., Holder, M. J., \& Smith, A. J. (2014). Inflammation and regeneration in the dentin-pulp complex: a double-edged sword. Journal of Endodontics, 40(4 Suppl), S46-S51. http://dx.doi.org/10.1016/j.joen.2014.01.021.

Couve, E., Osorio, R., \& Schmachtenberg, O. (2013). The amazing odontoblast: activity, autophagy, and aging. Journal of Dental Research, 92(9), 765-772. http://dx.doi.org/ 10.1177/0022034513495874.

de Almeida, L. F. D., Basso, F. G., Turrioni, A. P. S., De-Souza-Costa, C. A., \& Hebling, J. (2016). Metabolic activity of odontoblast-like cells irradiated with blue LED (455 nm). Lasers in Medical Science, 31(1), 119-125. http://dx.doi.org/10.1007/ s10103-015-1837-z.

Emelyanov, A. N., \& Kiryanova, V. V. (2015). Photomodulation of proliferation and differentiation of stem cells by the visible and infrared light. Photomedicine and Laser Surgery, 33(3), 164-174. http://dx.doi.org/10.1089/pho.2014.3830.

Frigo, L., Fávero, G. M., Lima, H. J. C., Maria, D. A., Bjordal, J. M., Joensen, J., \& LopesMartins, R. A. B. (2010). Low-level laser irradiation (InGaAlP-660\#xp\#nm) increases fibroblast cell proliferation and reduces cell death in a dose-dependent manner. Photomedicine and Laser Surgery, 28(Suppl. 1), S151-S156. http://dx.doi.org/10. 1089/pho.2008.2475.

Goldberg, M., \& Smith, A. J. (2004). CELLS and extracellular matrices of dentin and pulp: 
a biological basis for repair and tissue engineering. critical reviews in oral biology and medicine. An Official Publication of the American Association of Oral Biologists. Retrieved from http://www.ncbi.nlm.nih.gov/pubmed/14761897.

Holder, M. J., Milward, M. R., Palin, W. M., Hadis, M. A., \& Cooper, P. R. (2012). Effects of red light-emitting diode irradiation on dental pulp cells. Journal of Dental Research, 91(10), 961-966. http://dx.doi.org/10.1177/0022034512456040.

Huang, Y.-Y., Chen, A. C.-H., Carroll, J. D., \& Hamblin, M. R. (2009). Biphasic dose response in low level light therapy. Dose-Response: A Publication of International Hormesis Society, 7(4), 358-383. http://dx.doi.org/10.2203/dose-response09-027.

Imada, K., Tanaka, S., Ibaraki, Y., Yoshimura, K., \& Ito, S. (2014). Antifungal effect of 405-nm light on Botrytis cinerea. Letters in Applied Microbiology, 59(6), 670-676. http://dx.doi.org/10.1111/lam.12330.

Kienle, A., Michels, R., \& Hibst, R. (2006). Magnification-a new look at a long-known optical property of dentin. Journal of Dental Research. Retrieved from http://www. ncbi.nlm.nih.gov/pubmed/16998140.

Kim, H. K., Kim, J. H., Abbas, A. A., Kim, D.-O., Park, S.-J., Chung, J. Y., \& Yoon, T. R. (2009). Red light of $647 \mathrm{~nm}$ enhances osteogenic differentiation in mesenchymal stem cells. Lasers in Medical Science, 24(2), 214-222. http://dx.doi.org/10.1007/s10103008-0550-6.

Krämer, N., Lohbauer, U., García-Godoy, F., \& Frankenberger, R. (2008). Light curing of resin-based composites in the LED era. American Journal of Dentistry, 21(3), 135-142. Retrieved from http://www.ncbi.nlm.nih.gov/pubmed/18686762.

Kushibiki, T., Tajiri, T., Ninomiya, Y., \& Awazu, K. (2010). Chondrogenic mRNA expression in prechondrogenic cells after blue laser irradiation. Journal of Photochemistry and Photobiology. B, Biology, 98(3), 211-215. http://dx.doi.org/10. 1016/j.jphotobiol.2010.01.008.

Lewis, J. B., Wataha, J. C., Messer, R. L. W., Caughman, G. B., Yamamoto, T., \& Hsu, S. D. (2005). Blue light differentially alters cellular redox properties. Journal of Biomedical Materials Research. Part B Applied Biomaterials, 72(2), 223-229. http://dx.doi.org/10. 1002/jbm.b.30126.

Liebmann, J., Born, M., \& Kolb-Bachofen, V. (2010). Blue-light irradiation regulates proliferation and differentiation in human skin cells. The Journal of Investigative Dermatology, 130(1), 259-269. http://dx.doi.org/10.1038/jid.2009.194.

Man, J., Shelton, R. M., Cooper, P. R., \& Scheven, B. A. (2012). Low-intensity low-frequency ultrasound promotes proliferation and differentiation of odontoblast-like cells. Journal of Endodontics, 38(5), 608-613. http://dx.doi.org/10.1016/j.joen.2012. 01.015 .

Medlock, A. E., Shiferaw, M. T., Marcero, J. R., Vashisht, A. A., Wohlschlegel, J. A., Phillips, J. D., \& Dailey, H. A. (2015). Identification of the Mitochondrial Heme Metabolism Complex. PloS One, 10(8), http://dx.doi.org/10.1371/journal.pone. 0135896 e0135896.

Neupane, J., Ghimire, S., Shakya, S., Chaudhary, L., \& Shrivastava, V. P. (2010). Effect of light emitting diodes in the photodynamic therapy of rheumatoid arthritis. Photodiagnosis and Photodynamic Therapy, 7(1), 44-49. http://dx.doi.org/10.1016/j. pdpdt.2009.12.006.

Nicholson, J. W., \& Czarnecka, B. (2008). The biocompatibility of resin-modified glassionomer cements for dentistry. Dental Materials: Official Publication of the Academy of Dental Materials, 24(12), 1702-1708. http://dx.doi.org/10.1016/j.dental.2008.04. 005.

Oliveira, C. F., Basso, F. G., Lins, E. C., Kurachi, C., Hebling, J., Bagnato, V. S., \& de Souza Costa, C. A. (2011). In vitro effect of low-level laser on odontoblast-like cells. Laser Physics Letters, 8(2), 155-163. http://dx.doi.org/10.1002/lapl.201010101.

Peplow, P. V., Chung, T.-Y., Ryan, B., \& Baxter, G. D. (2011). Laser photobiomodulation of gene expression and release of growth factors and cytokines from cells in culture: a review of human and animal studies. Photomedicine and Laser Surgery, 29(5), 285-304. http://dx.doi.org/10.1089/pho.2010.2846.

Posten, W., Wrone, D. A., Dover, J. S., Arndt, K. A., Silapunt, S., \& Alam, M. (2005). Lowlevel laser therapy for wound healing: mechanism and efficacy. Dermatologic Surgery. Official Publication for American Society for Dermatologic Surgery, 31(3), 334-340. Retrieved from http://www.ncbi.nlm.nih.gov/pubmed/15841638 \&\#160.

Prindeze, N. J., Moffatt, L. T., \& Shupp, J. W. (2012). Mechanisms of action for light therapy: a review of molecular interactions. Experimental Biology and Medicine (Maywood, N.J.), 237(11), 1241-1248. http://dx.doi.org/10.1258/ebm.2012. 012180.

Pyo, S.-J., Song, W.-W., Kim, I.-R., Park, B.-S., Kim, C.-H., Shin, S.-H., \& Kim, Y. D. (2013). Low-level laser therapy induces the expressions of BMP-2, osteocalcin, and TGF- $\beta 1$ in hypoxic-cultured human osteoblasts. Lasers in Medical Science, 28(2), 543-550. http://dx.doi.org/10.1007/s10103-012-1109-0.

Read, S. M., \& Northcote, D. H. (1981). Minimization of variation in the response to different proteins of the Coomassie blue G dye-binding assay for protein. Analytical Biochemistry, 116(1), 53-64. Retrieved from http://www.ncbi.nlm.nih.gov/pubmed/ 7304986.

Saruwatari, L., Aita, H., Butz, F., Nakamura, H. K., Ouyang, J., Yang, Y., \& Ogawa, T. (2005). Osteoblasts generate harder, stiffer, and more delamination-resistant mineralized tissue on titanium than on polystyrene, associated with distinct tissue micro- and ultrastructure. Journal of Bone and Mineral Research: The Official Journal of the American Society for Bone and Mineral Research, 20(11), 2002-2016. http://doi. org/10.1359/JBMR.050703.

Tjäderhane, L., \& Haapasalo, M. (2009). The dentin-pulp border: a dynamic interface between hard and soft tissues. Endodontic Topics, 20(1), 52-84. http://dx.doi.org/10 1111/j.1601-1546.2012.00266.x.

Turrioni, A., Basso, F., Montoro, L., Almeida, L., de Costa, C. S., \& Hebling, J. (2014). Phototherapy up-regulates dentin matrix proteins expression and synthesis by stem cells from human-exfoliated deciduous teeth. Journal of Dentistry, 42(10), 1292-1299. http://doi.org/10.1016/j.jdent.2014.07.014.

Turrioni, A. P., Basso, F. G., Montoro, L. A., Almeida, L. F. D., de Souza Costa, C. A., \& Hebling, J. (2016). Transdentinal photobiostimulation of stem cells from human exfoliated primary teeth. International Endodontic Journal, n/a-n/a. http://doi.org/10. 1111/iej.12665.

Turrioni, A. P. S., Basso, F. G., Alonso, J. R. L., de Oliveira, C. F., Hebling, J., Bagnato, V. S., \& de Souza Costa, C. A. (2015). Transdentinal cell photobiomodulation using different wavelengths. Operative Dentistry, 40(1), 102-111. http://doi.org/10.2341/ 13-370-L.

Turrioni, A. S., Alonso, J., Basso, F. G., Moriyama, L., Hebling, J., Bagnato, V., \& De Souza, C. A. (2013). LED light attenuation through human dentin: a first step toward pulp photobiomodulation after cavity preparation. American Journal of Dentistry, 26(6), 319-323. Retrieved from http://www.ncbi.nlm.nih.gov/pubmed/24640435.

Wataha, J. C., Lockwood, P. E., Lewis, J. B., Rueggeberg, F. A., \& Messer, R. L. W. (2004). Biological effects of blue light from dental curing units. Dental Materials: Official Publication of the Academy of Dental Materials, 20(2), 150-157. Retrieved from http:// www.ncbi.nlm.nih.gov/pubmed/14706798.

Zaccara, I. M., Ginani, F., Mota-Filho, H. G., Henriques, Á. C. G., \& Barboza, C. A. G. (2015). Effect of low-level laser irradiation on proliferation and viability of human dental pulp stem cells. Lasers in Medical Science, 30(9), 2259-2264. http://doi.org/ 10.1007/s10103-015-1803-9. 